\title{
Academic Advising, Remedial Courses, and Legislative Mandates: An Exploration of Academic Advising in Florida Community Colleges with Optional Developmental Education
}

\author{
Chenoa S. Woods ${ }^{1} \cdot$ Keith Richard $^{1} \cdot$ Toby Park $^{1}$.

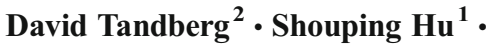 \\ Tamara Bertrand Jones ${ }^{1}$
}

Published online: 28 November 2016

(C) The Author(s) 2016. This article is published with open access at Springerlink.com

\begin{abstract}
In this article we report on our exploration of academic advising practices at 19 community colleges in the Florida College System after the implementation of Senate Bill 1720. This bill made developmental education optional for many students and mandated that colleges provide academic advising for all new students. Descriptive statistics of survey responses from college administrators uncovered academic advising patterns across these 19
\end{abstract}

Chenoa S. Woods is a research faculty member in the Center for Postsecondary Success at Florida State University. She earned her Ph.D. from the University of California, Irvine in Education Policy and Social Context. Her primary research interests include college access, choice, and success with an emphasis on precollege counseling and preparation. Correspondence regarding this article can be sent to cwoods@ fsu.edu.

Keith Richard is a graduate research assistant in the Center for Postsecondary Success and a doctoral candidate in the Sociology department at Florida State University. His research interests include community college reform, sociology of education, and social inequalities.

Toby Park is Associate Director of the Center for Postsecondary Success and Assistant Professor of Education Policy at Florida State University. He earned his Ph.D. in Education Policy from Vanderbilt University, and his primary research utilizes quasi-experimental techniques to investigate student outcomes in postsecondary education and policy initiatives that improve student success.

David Tandberg is a principal policy analyst with the State Higher Education Executive Officers Organization. He earned his Ph.D. in Higher Education Policy from Pennsylvania State University, and his research interests center on state higher education policy, politics, and finance.

Shouping $\mathbf{H u}$ is the founding Director of the Center for Postsecondary Success and the Louis W. and Elizabeth N. Bender endowed Professor of Higher Education at Florida State University. He earned his Ph.D. in Higher Education from Indiana University; and his research interests include student postsecondary readiness, outcomes, and success and public policy.

Tamara Bertrand Jones is Associate Director of the Center for Postsecondary Success and Associate Professor of Higher Education at Florida State University. Her research uses culturally responsive frameworks to examine the sociocultural contexts of evaluation and education for underrepresented populations in academia. She earned her Ph.D. from Florida State University in Research and Evaluation Methods.

Chenoa S. Woods

cwoods@fsu.edu 
community colleges. Our findings indicated that many administrators agreed that their advising practices were effective and that most colleges used a variety of advising tools. In an era of greater student choice, colleges diversified their advising protocols and methods of guiding students in a variety of ways.

Keywords Developmental education · Academic advising $\cdot$ Community colleges

Developmental education (DE) can be understood as preparatory coursework taken at colleges and universities designed to help underprepared students master important skills but not counting for college credit (Scott-Clayton and Rodriguez 2012). It has long been a part of the United States college education experience (Higbee, Arendale, and Lundell 2005); and it has been hotly contested, in part because research has yielded mixed findings regarding its effectiveness (see Bailey, Jeong, and Cho 2010; Boatman 2012; Boatman and Long 2010; Calcagno and Long 2008) and its large financial costs (Melguizo, Hagedorn, and Cypers 2008; Pretlow and Wathington 2012). Historically, underprepared American college students have been assigned to mandatory DE. These classes have been offered by subject (i.e., reading, writing, and mathematics) and at varying ability levels. Depending on how much DE was deemed necessary based on placement test scores, students could spend more than a year completing the developmental courses needed to prepare them for college-level courses (Bailey et al. 2010).

\section{Florida Senate Bill 1720}

Departing from this traditional model of mandatory DE, the State of Florida passed Senate Bill 1720 (SB 1720) in 2013, which affected the Florida College System (FCS), the statewide community college system. SB 1720 granted many community college students the opportunity to opt out of placement tests and developmental coursework, regardless of academic preparation. Students who were given this option were defined as exempt, and SB 1720 categorized students as exempt if they entered a Florida public high school in ninth grade in the 2003-2004 academic year or later and graduated with a standard high school diploma or if they were active duty military personnel. Further, exempt students were no longer required to take a placement test upon enrolling in college.

The legislation also required that the community colleges offer academic advising to all incoming students, regardless of their exempt or non-exempt status. The academic advising component of SB 1720 was a significant change; to our knowledge few states have used legislative action to mandate academic advising (see Center for College Readiness 2000 for an exception). However, despite the specific attention the

1 Center for Postsecondary Success, Florida State University, 1114 W. Call St., Stone Bldg. 1208G, Tallahassee, FL 32306-4452, USA

2 State Higher Education Executive Officers Organization, 3035 Center Green Drive, Suite 100, Boulder, CO 80301-2205, USA 
legislation paid to advising, it provided great leeway for how colleges could adapt and enhance their existing advising practices.

In addition to augmenting current advising practices, the legislation required that colleges offer developmental courses employing new instructional methods, which included self-paced computer-based courses, condensed or shortened courses, courses contextualized within major disciplines, and supplemental support for college-level classes. These new course offerings combined with the option to enroll without placement test scores added complexity to intake and advising processes. Further, SB 1720 required colleges to offer meta-majors, which are described as major-course sequences that determine which gateway courses apply to which majors (Collins 2013). According to the legislation, advising must include the option to enroll in DE if placement measures indicated students needed to improve basic skills. After the legislation was approved, but before full implementation, colleges were required to submit implementation plans to the State that detailed their plans to address the legislative requirements.

The implementation of new policies provided an important opportunity to investigate the changes at the community colleges. For the study we report here we analyzed responses from a survey distributed to college administrators in spring 2015-the midpoint of the academic year in which the legislation change went into effect - and explored how administrators perceived the initial implementation of their institution's implementation plans to address the legislation. In this study we focused on the academic advising component of SB 1720. Specifically, we examined administrators' perceptions of academic advising practices and the degree to which the administrators perceived these practices to be effective.

To provide context for this study, we reference a quantitative report using studentlevel administrative data assessing student outcomes following the reform $\mathrm{CHu}$ et al. 2016). The authors found that enrollment in developmental mathematics, reading, and writing courses fell in 2014 by 11 to 21 percentage points and that the pass rates of these courses decreased by 1.5 to 3.2 percentage points for first-time-in-college (FTIC) students. Subsequently, students enrolled in gateway courses at higher rates in 2014. Among students enrolled in English and math gateway courses, pass rates, however, declined by 3.4 and 8.7 percentage points, respectively. Nevertheless, cohort-based pass rates indicated that the proportion of FTIC students entering college in 2014 had higher pass rates by 9.4 percentage points in English and 6.1 percentage points in mathematics.

\section{Review of Related Literature}

While it was expected that there would be some similarities among the implementation processes of SB 1720, research on effective policy implementation and previous studies about the legislation suggested that different policies and practices have also emerged among the FCS institutions (Hu et al. 2014, 2015; Park, Tandberg, Hu, and Hankerson 2016). The variability of academic advising practices at different colleges was likely influenced by the local context, including issues pertaining to communication of policy standards and decisions, the capabilities of an institution based on available resources, and the dispositions of the individuals overseeing implementation 
(Honig 2006; McLaughlin 1987, 2006; Spillane, Reiser, and Gomez 2006; Van Meter and Van Horn 1975).

\section{Academic Advising to Promote Student Success}

Academic advising is a crucial part of students' undergraduate experiences, particularly when new policies or practices have been implemented at the college and when students are unfamiliar with college processes such as course registration (see Irlbeck, Adams, Akers, Burris, and Jones 2014; Swecker, Fifolt, and Searby 2013). Importantly, there is ample evidence that effective academic advising promotes student success (see Backhus 1989; Bahr 2008; Kirk-Kuwaye and Nishida 2001; Kot 2014; Swecker et al. 2013; Young-Jones, Burt, Dixon, and Hawthorne 2013). For community college students in particular, advising may be crucial during the enrollment process so that students are aware of the differences between remedial and college credit-bearing classes (Person, Rosenbaum, and Deil-Amen 2006). Indeed, community college students who were planning to transfer, compared to posttransfer students, indicated that advising that connected their general education to majors, career options, and degree options was especially important (Allen, Smith, and Muehleck 2013). Therefore, we believed it was important to examine administrators' perceptions of advising effectiveness when college-wide course selection policies have changed.

Effective advising is essential because of the positive impact it can have on educational outcomes. For example, the use of centralized advising centers has been positively related to students' first and second-semester grade point averages (GPAs) and overall first year GPA and negatively related to student attrition (Backhus 1989; Kot 2014). Additionally, Swecker, Fifolt, and Searby (2013) found that for first-generation college students every meeting with an advisor increased the odds of retention by $13 \%$. Similarly, meeting with an advisor was positively associated with student responsibility, self-efficacy, study skills, and perceived support (Young-Jones et al. 2013).

While simply having access to advising services can be beneficial, institutions vary in their level of involvement with students. Kirk-Kuwaye and Nishida (2001) discussed an advising approach of high institutional involvement where students are viewed as transitional. According to these authors, high institutional involvement occurs when educators view students as underprepared for the transition to college, particularly for students with academic problems. High involvement institutions may initiate contact with an academically at-risk student, address a variety of issues, facilitate communication between the student and the instructor, and require individual advising. Regardless of the level of institutional involvement, academic advisors face challenges in completing their duties to the best of their abilities, largely due to limited time and resources. Student services are often dispersed across campus, advisors have limited time to meet with students, and students may be unable to meet with the same advisor in subsequent advising sessions, thus hindering the ability to form meaningful student-advisor relationships (Kalamkarian and Karp 2015).

Large student-advisor caseloads do not allow for advisors to spend adequate time with students or initiate multiple meetings (Karp and Stacey 2013). Indeed, students have noted that limited advisor availability was one reason for not meeting with their advisor (Feghali, Zbib, and Hallal 2011). In efforts to combat these challenges, colleges have increased their use of online advising, early alert systems, and other technology-based teaching and advising practices, which may be a method of reaching more students (Dahlstrom, de Boor, Grunwald, and Vockley 2011; Krumm 
et al. 2014). Online advising tools have been shown to be effective and efficient (Feghali et al. 2011); yet the face-to-face component, which allows for relationship building, remains critical (Kalamkarian and Karp 2015).

Face-to-face and online advising provide different benefits to the students and the institutions; and proactive advising, often called intrusive advising, which may be implemented online or in person, allows for early identification of critical issues such as academic probation (Varney 2012). Further, research has found that effective advising occurs at multiple time points (Karp and Stacey 2013), ideally prior to registration each semester. Mandatory new student orientations (Dadgar, Nodine, Bracco, and Venezia 2014; Varney 2007) and intentional communication and monitoring (Varney 2012) may also combat issues of limited resources.

Regarding DE reform specifically, several states across the country have implemented a multiple measures advising policy that requires multiple data points to determine how best to place students into classes. For example, North Carolina implemented a hierarchical placement policy by exempting students from DE coursework if they had graduated from high school within the last 5 years and met a minimum GPA, ACT/SAT scores, or placement test scores (Bracco et al. 2015; Duffy 2015). Some community colleges have begun to use a combination of high school coursework, grades, and overall GPA in their placement processes, many with promising outcomes for student success (Long Beach Promise 2013; Ngo and Kwon 2015; Scott-Clayton, Crosta, and Belfield 2014). Further, community college students indicated that having advisors consider their "skills, abilities, and interests," or non-cognitive factors that would not be captured on a standardized test was important when assisting with course selection and registration (Allen et al. 2013, p. 336).

\section{Policy Implementation}

While the extant literature identifies a variety of effective academic advising practices, we expected that the FCS colleges would implement varying advising policies in response to SB 1720. These differences would arise from policy ambiguity, local resources, and key individuals in the local context. We now explain Kotter's (1995) eight steps of organizational change and apply it to the context of Florida's DE reform process.

Kotter (1995) posited that organizational leaders need to communicate the crucial need for change by identifying the crisis or key opportunities and collaborate with others who can enact change within the organization. Park, Tandberg, Hu, and Hankerson (2016) indicated that each of the 28 FCS institutions formed an implementation team; however, it was evident that these teams consisted of people from various departments. Thus, influences from different stakeholders at the institutions may have affected the execution of the implementation plans differently. It is likely that differences in the organizational members and departments involved in the reform process have resulted in different implementation of new advising practices (Safran and Visher 2010).

Kotter recommended that organizational leaders should develop a vision, implement plans to realize the vision, communicate the vision, and enable other stakeholders to implement the vision. Institutions submitted implementation plans for review by the Division of Florida Colleges, which provided the opportunity for colleges to establish their vision for change. SB 1720 did not specify the academic advising practices that FCS colleges should implement, thus allowing for the institutions to create their own visions, but with policy ambiguity. Policy ambiguity affects the degree of consistency in understanding the policy at the different implementation sites, the degree 
to which local factors play a substantial role, and the variation of important actors at the sites (Matland 1995; Percival 2004). While local resources affect what change is feasible, individual and institutional ideologies might also play a role in the augmented advising practices. Specifically, the motivation, commitment, and ideologies of administrators across institutions can affect how a policy change is handled (Perin 2006).

Kotter (1995) also recommended eliminating obstacles to achieving the vision. However, eliminating barriers can be difficult when conflicting goals emerge among the individuals implementing change; and conflicting goals are more likely to arise when a policy requires major organizational changes (Brodkin 2008; Van Meter and Van Horn 1975). It is possible though that the members of the implementation teams can effectively collaborate and benefit from divergent opinions of their members (Kezar 2014). Additionally, there may be a variety of effective organizational structures that implement DE policy. For example, Safran and Visher (2010) found that there was considerable variation in the structures that evaluated student assessment and placement into DE courses across three community colleges.

Finally, implementing effective organizational change also includes creating plans for shortterm gains, altering ineffective practices to continue to enact change, and institutionalizing the new practices (Kotter 1995). These are the stages of organizational change that this study most closely explores.

\section{The Study}

This study examined administrators' descriptions of their college's academic advising practices and their initial impressions of the implementation of their institutional plans. Using surveys from high-level administrators across the FCS, we sought to understand the impact of SB 1720 following its first semester of implementation. Because many colleges had already implemented different aspects of academic advising programs, we could not quantitatively determine which advising practices resulted directly from the legislation. However, we were able to assess the similarities and differences of advising practices as perceived by college administrators at the FCS institutions. This examination revealed whether FCS institutions implemented similar academic advising practices and identified successes and challenges in light of SB 1720, which is essential for understanding student success in future research of this policy.

\section{Sample}

After receiving approval from our Institutional Review Board, we invited FCS leaders representing all 28 colleges to participate in an online survey about the execution of SB 1720. At some colleges two administrators replied to the survey, so there were 32 total respondents. We removed from our sample those with incomplete data and also deleted five respondents who represented institutions with multiple participants. When we received multiple responses from a single institution, we retained one response from each college so as not to duplicate responses from a single institution, using data from the most senior representative for each college. Nearly $65 \%$ of respondents in our analytic sample were provosts or vice provosts, $17.6 \%$ were deans, and $17.6 \%$ were other college officials.

Our analytic sample included data from administrators at 19 of the 28 FCS institutions (67.9\%), which on average, are characterized by the following descriptive statistics: The average estimated full-time equivalent enrollment was 12,539 students, $59.5 \%$ of whom were female (Table 1). On 
Table 1 Summary statistics of institutional characteristics for Florida College System respondents and nonrespondents

\begin{tabular}{|c|c|c|c|c|c|c|}
\hline & \multicolumn{2}{|c|}{ Respondents } & \multicolumn{2}{|c|}{ Non-respondents } & \multirow[t]{2}{*}{$t$} & \multirow[t]{2}{*}{$p$} \\
\hline & $\begin{array}{l}\text { Mean or } \\
\text { Percent }\end{array}$ & $\begin{array}{l}\text { Standard } \\
\text { Deviation }\end{array}$ & $\begin{array}{l}\text { Mean or } \\
\text { Percent }\end{array}$ & $\begin{array}{l}\text { Standard } \\
\text { Deviation }\end{array}$ & & \\
\hline \multicolumn{7}{|l|}{ Institutional Demographics } \\
\hline $\begin{array}{l}\text { Estimated Full-Time Equivalent En- } \\
\text { rollment }\end{array}$ & 12539.42 & 2968.63 & 11664.67 & 2927.33 & -0.183 & 0.856 \\
\hline Female & $59.52 \%$ & $3.04 \%$ & $59.25 \%$ & $0.68 \%$ & -0.235 & 0.816 \\
\hline Part-time Students & $63.01 \%$ & $4.85 \%$ & $57.87 \%$ & $4.79 \%$ & -1.421 & 0.167 \\
\hline American Indian & $0.42 \%$ & $0.23 \%$ & $0.37 \%$ & $0.04 \%$ & -0.697 & 0.492 \\
\hline Asian & $2.25 \%$ & $1.04 \%$ & $2.15 \%$ & $0.18 \%$ & -0.277 & 0.784 \\
\hline Black & $16.86 \%$ & $6.69 \%$ & $13.76 \%$ & $2.78 \%$ & -1.059 & 0.299 \\
\hline Hispanic/Latino & $14.84 \%$ & $15.24 \%$ & $17.67 \%$ & $2.71 \%$ & 0.520 & 0.608 \\
\hline Pacific Islander & $0.19 \%$ & $0.15 \%$ & $0.15 \%$ & $0.03 \%$ & -0.631 & 0.534 \\
\hline White & $58.08 \%$ & $17.84 \%$ & $58.64 \%$ & $5.65 \%$ & 0.078 & 0.938 \\
\hline Multiethnic & $1.81 \%$ & $1.12 \%$ & $1.46 \%$ & $0.15 \%$ & -0.904 & 0.374 \\
\hline Unknown & $4.70 \%$ & $4.88 \%$ & $4.77 \%$ & $0.93 \%$ & 0.039 & 0.970 \\
\hline \multicolumn{7}{|l|}{ Financial Aid Awards } \\
\hline Average Financial Aid Award & $\$ 4,152.95$ & $\$ 1,221.27$ & $\$ 3,981.78$ & 111.92 & 0.6856 & -0.4095 \\
\hline Percent Receiving Aid & $57.63 \%$ & $14.64 \%$ & $49.22 \%$ & $2.11 \%$ & -1.6398 & 0.1131 \\
\hline Average Pell Grant Award & $\$ 3,620.95$ & $\$ 566.89$ & $\$ 3,620.95$ & $\$ 63.03$ & -0.2589 & 0.7978 \\
\hline Percent Receiving Pell Grant & $42.84 \%$ & $6.82 \%$ & $42.44 \%$ & $1.94 \%$ & -0.1506 & 0.8814 \\
\hline \multicolumn{7}{|l|}{ Instructional Staff } \\
\hline $\begin{array}{l}\text { Percent Full-Time Minority Instruc- } \\
\text { tors }\end{array}$ & $19.37 \%$ & $13.39 \%$ & $20.74 \%$ & 0.03 & 0.278 & 0.783 \\
\hline Percent Part-Time Instructors & $69.42 \%$ & $6.65 \%$ & $71.21 \%$ & 0.02 & 0.672 & 0.508 \\
\hline $\begin{array}{l}\text { Percent Part-Time Minority Instruc- } \\
\text { tors }\end{array}$ & $21.72 \%$ & $13.59 \%$ & $20.72 \%$ & 0.03 & -0.198 & 0.845 \\
\hline Average Students Per Faculty & 22.68 & 4.35 & 22.56 & 1.09 & -0.079 & 0.938 \\
\hline \multicolumn{7}{|l|}{ Expenditures (2013) } \\
\hline $\begin{array}{l}\text { Instructional expenses as a percent of } \\
\text { total core expenses }\end{array}$ & $41.47 \%$ & $3.50 \%$ & $42.33 \%$ & $1.93 \%$ & 0.490 & 0.628 \\
\hline $\begin{array}{l}\text { Academic support expenses as a } \\
\text { percent of total core expenses }\end{array}$ & $10.63 \%$ & $3.76 \%$ & $9.67 \%$ & $0.90 \%$ & -0.688 & 0.498 \\
\hline $\begin{array}{l}\text { Student service expenses as a percent } \\
\text { of total core expenses }\end{array}$ & $12.60 \%$ & $2.70 \%$ & $12.11 \%$ & $0.68 \%$ & -0.458 & 0.651 \\
\hline Instructional expenses per FTE & $\$ 4,072.63$ & $\$ 824.66$ & $\$ 4,095.44$ & $\$ 417.64$ & 0.058 & 0.954 \\
\hline Academic support expenses per FTE & $\$ 1,051.26$ & $\$ 465.53$ & $\$ 949.00$ & $\$ 144.28$ & -0.555 & 0.584 \\
\hline Student service expenses per FTE & $\$ 1,255.32$ & $\$ 447.51$ & $\$ 1,160.67$ & $\$ 86.05$ & -0.586 & 0.563 \\
\hline $\mathrm{n}$ & 19 & & 9 & & & \\
\hline
\end{tabular}

average, the majority of students at the institutions were White (58.1\%) while $16.9 \%$ were Black, and $14.8 \%$ Hispanic/Latino. Sixty-three percent of the students at these institutions enrolled on a part-time basis, and more than half $(57.6 \%)$ received financial aid. It is important to note that we cannot generalize our findings across the FCS institutions due to our response rate. However, we 
conducted a series of t-tests to determine whether responding and non-responding institutions differed based on institutional characteristics. We examined data from the Integrated Postsecondary Education Data System (IPEDS), a dataset that allows for comparisons of over 7,000 institutions, to understand the institutional characteristics of each community college in the FCS. We found no significant differences between responding and non-responding institutions in terms of IPEDS institutional characteristics (see Table 1).

\section{Survey Design and Analysis}

Whereas the survey used in this study covered multiple aspects of the implementation of the new legislation, this study focused specifically on survey questions regarding the role of academic advising. We asked the administrators about the tools and techniques used during advising, the effectiveness of advising, new student orientation, meta-majors, and advising resources and availability.

Some of the questions were loosely based on questions asked in the first administrator survey (Park et al. 2016), which differed in that it focused mostly on administrators' perceptions of the legislation itself and their expectations of how it would be implemented. Our qualitative analysis of focus group interviews with FCS personnel and students ( $\mathrm{Hu}$ et al. 2015) and our understanding of institutions' plans (Park et al. 2016; Hu et al. 2014) also informed the survey design. The study we report here utilized descriptive statistics in order to understand administrators' perspectives of colleges' advising practices.

\section{Results}

We present our descriptive results detailing administrators' perceptions of four main areas: academic advising practices and tools, advising effectiveness, new student orientations and meta-majors, and advising resources and availability.

\section{Academic Advising Practices and Tools}

First, we examined the practices and tools colleges were using during the first and second semester of the implementation of SB 1720. The survey question for these variables was, "Since implementing the institutional plan, to what extent do you agree or disagree with the following statements?" The majority $(68.4 \%, n=13)$ of respondents agreed or strongly agreed that their college used transcripts, checklists, individual education plans, and degree maps in advising (Table 2). Nearly as many $(63.2 \%, n=12)$ agreed that their college also considered noncognitive factors such as family obligations, learning styles, and motivation in the advising process. Thus, the use of a combination of advising tools was common across the colleges.

\section{Advising Effectiveness}

Next, we considered administrators' perceptions of the effectiveness of their advising practices. The majority $(68.4 \%, n=13)$ of administrators agreed or strongly agreed that their advising system was effective regarding students' exempt status under SB 1720 and students' DE options (Table 3). Slightly fewer $(57.9 \%, n=11)$ agreed or strongly agreed that advising was effective overall or that the course registration system assisted with students' exemption status. However, only a few 
Table 2 Advising practices and tools

\begin{tabular}{|c|c|c|c|c|c|}
\hline & $\begin{array}{l}\text { Disagree or } \\
\text { Strongly } \\
\text { Disagree }\end{array}$ & $\begin{array}{l}\text { Somewhat } \\
\text { Disagree }\end{array}$ & Neutral & $\begin{array}{l}\text { Somewhat } \\
\text { Agree }\end{array}$ & $\begin{array}{l}\text { Agree or } \\
\text { Strongly } \\
\text { Agree }\end{array}$ \\
\hline College uses intrusive advising & 5.3 & 10.5 & 0 & 52.6 & 31.6 \\
\hline $\begin{array}{l}\text { Advising considers non-cognitive fac- } \\
\text { tors }\end{array}$ & 10.5 & 5.3 & 0 & 21.1 & 63.2 \\
\hline College uses early warning system & 0 & 10.5 & 10.5 & 31.6 & 47.4 \\
\hline College uses transcripts in advising & 10.5 & 0 & 10.5 & 10.5 & 68.4 \\
\hline College uses checklist in advising & 10.5 & 5.3 & 10.5 & 5.3 & 68.4 \\
\hline Advisors use individual education plans & 5.3 & 10.5 & 5.3 & 10.5 & 68.4 \\
\hline Advisors use degree maps & 5.3 & 5.3 & 0 & 21.1 & 68.4 \\
\hline
\end{tabular}

Numbers represent percentages of responding institutions

agreed or strongly agreed that the early warning system $(21.1 \%, n=4)$ or the use of technology in advising $(15.8 \%, n=3)$ were effective. Further, just two respondents agreed or strongly agreed that academic advising was meeting students' needs. Although advisors were using a variety of tools and practices, administrators' responses revealed that not all tools were effective. More troubling is that just two institutions responded that advising was related to students' success.

\section{New Student Orientations and Meta-Majors}

Academic advisors were often involved in the new student orientation process, the point at which students were first introduced to their meta-major options. More than half $(57.9 \%, n=11)$ of respondents agreed or strongly agreed that their new student orientation changed following the implementation of SB 1720; yet only 10.5\% $(n=2)$ agreed that they offered separate orientations for students who were exempt or non-exempt (Table 4).

Table 3 Perceived effectiveness of academic advising practices and tools

\begin{tabular}{|c|c|c|c|c|c|}
\hline & $\begin{array}{l}\text { Disagree or } \\
\text { Strongly } \\
\text { Disagree }\end{array}$ & $\begin{array}{l}\text { Somewhat } \\
\text { Disagree }\end{array}$ & Neutral & $\begin{array}{l}\text { Somewhat } \\
\text { Agree }\end{array}$ & $\begin{array}{l}\text { Agree or } \\
\text { Strongly } \\
\text { Agree }\end{array}$ \\
\hline Academic advising effective & 0 & 5.3 & 5.3 & 31.6 & 57.9 \\
\hline $\begin{array}{l}\text { Advising system effective for exemption } \\
\text { status }\end{array}$ & 0 & 5.3 & 5.3 & 21.1 & 68.4 \\
\hline Advising system effective for DE options & 10.5 & 0 & 5.3 & 15.8 & 68.4 \\
\hline Intrusive advising has been effective & 5.3 & 0 & 15.8 & 36.8 & 42.1 \\
\hline $\begin{array}{l}\text { Course registration system assists with } \\
\text { exemption status }\end{array}$ & 10.5 & 0 & 5.3 & 26.3 & 57.9 \\
\hline Early warning system is effective & 5.3 & 5.3 & 21.1 & 47.4 & 21.1 \\
\hline Use of technology effective in advising & 10.5 & 21.1 & 26.3 & 26.3 & 15.8 \\
\hline $\begin{array}{l}\text { Academic advising related to increased } \\
\text { student success }\end{array}$ & 0 & 0 & 31.6 & 21.1 & 47.4 \\
\hline Academic advising meets students' needs & 15.8 & 21.1 & 10.5 & 42.1 & 10.5 \\
\hline
\end{tabular}

Numbers represent percentages of responding institutions 
Table 4 New student orientations and meta-majors

\begin{tabular}{|c|c|c|c|c|c|}
\hline & $\begin{array}{l}\text { Disagree or } \\
\text { Strongly } \\
\text { Disagree }\end{array}$ & $\begin{array}{l}\text { Somewhat } \\
\text { Disagree }\end{array}$ & Neutral & $\begin{array}{l}\text { Somewhat } \\
\text { Agree }\end{array}$ & $\begin{array}{l}\text { Agree or } \\
\text { Strongly } \\
\text { Agree }\end{array}$ \\
\hline NSO changed after SB 1720 & 5.3 & 0 & 10.5 & 26.3 & 57.9 \\
\hline $\begin{array}{l}\text { Separate NSO for exempt and non-exempt } \\
\text { students }\end{array}$ & 73.7 & 10.5 & 5.3 & 0 & 10.5 \\
\hline $\begin{array}{l}\text { Advising for meta-majors related to DE ad- } \\
\text { vising }\end{array}$ & 26.3 & 0 & 21.1 & 15.8 & 36.8 \\
\hline Students understand meta-major options & 10.5 & 10.5 & 26.3 & 26.3 & 26.3 \\
\hline Students required to declare meta-major & 26.3 & 10.5 & 10.5 & 26.3 & 26.3 \\
\hline
\end{tabular}

Numbers represent percentages of responding institutions

There was wide variation among the administrators' perceptions of their meta-majors. Five persons disagreed or strongly disagreed that advising for meta-majors was related to advising for DE, yet seven strongly agreed or agreed. Further, about one-quarter $(26.3 \%, n=5)$ required their students to declare a meta-major, and the same number did not (as indicated by disagreement or strong disagreement with the statement). Similarly, only about one-quarter $(26.3 \%, n=$ 5 ) agreed or strongly agreed that their students understood the meta-major options. As evidenced by the low levels of agreement on these statements, we concluded that metamajors have not yet been fully implemented into the advising process.

\section{Advising Resources and Availability}

Finally, we explored administrators' perceptions of advising resources and availability. Although each administrator in our sample agreed or strongly agreed that advising was available to all students and the majority $(84.2 \%, n=16)$ perceived it as well advertised to students, fewer than half $(47.4 \%, n=9)$ required students to participate (Table 5). Some colleges have experienced changes in their advising program specifically since implementing SB 1720. That is, more than half $(52.6 \%, n=10)$ of our respondents agreed or strongly agreed that they have increased the types of advising offered, whereas less than one-third $(31.6 \%, n=6)$ have increased the amount of advising offered, such as extending advising office hours or expanding programming. Likewise, $42.1 \%(n=8)$ agreed or strongly agreed that they have seen increased use of advising services by their students. However, just $15.8 \%(n=3)$ agreed or strongly agreed that their advisors had ample time to meet with students; and only one institutional representative agreed or strongly agreed that there were sufficient staff members to handle the advising caseload.

In addition to the above analyses, we conducted a series of ordered logistic regression equations to determine how administrators' perceptions of their academic advising practices varied by institutional characteristics. However, few results were significant; and no patterns emerged (results available upon request).

\section{Discussion}

This study examined the initial academic advising plans and processes of 19 community colleges throughout Florida as they addressed the requirements of SB 1720. Given the broad 
Table 5 Academic advising resources and availability

\begin{tabular}{|c|c|c|c|c|c|}
\hline & $\begin{array}{l}\text { Disagree or } \\
\text { Strongly } \\
\text { Disagree }\end{array}$ & $\begin{array}{l}\text { Somewhat } \\
\text { Disagree }\end{array}$ & Neutral & $\begin{array}{l}\text { Somewhat } \\
\text { Agree }\end{array}$ & $\begin{array}{l}\text { Agree or } \\
\text { Strongly } \\
\text { Agree }\end{array}$ \\
\hline $\begin{array}{l}\text { College has increased types of academic } \\
\text { advising }\end{array}$ & 10.5 & 15.8 & 5.3 & 15.8 & 52.6 \\
\hline $\begin{array}{l}\text { College has increased amount of academic } \\
\text { advising }\end{array}$ & 21.1 & 5.3 & 26.3 & 15.8 & 31.6 \\
\hline $\begin{array}{l}\text { College has seen increased use of academic } \\
\text { advising }\end{array}$ & 10.5 & 0 & 21.1 & 26.3 & 42.1 \\
\hline Academic advising required & 26.3 & 10.5 & 0 & 15.8 & 47.4 \\
\hline Academic advising available to all students & 0 & 0 & 0 & 0 & 100 \\
\hline $\begin{array}{l}\text { Academic advising well-advertised to stu- } \\
\text { dents }\end{array}$ & 5.3 & 0 & 0 & 10.5 & 84.2 \\
\hline $\begin{array}{l}\text { Advisors have ample time to meet with } \\
\text { students }\end{array}$ & 31.6 & 21.1 & 15.8 & 15.8 & 15.8 \\
\hline $\begin{array}{l}\text { College has sufficient staff to handle academic } \\
\text { advising }\end{array}$ & 52.6 & 21.1 & 0 & 21.1 & 5.3 \\
\hline
\end{tabular}

Numbers represent percentages of responding institutions

language of the legislation as to how colleges could implement their advising programs, we found both similarities and differences in academic advising practices across the sample. Many colleges relied on a variety of advising tools, and few reported sufficient advising resources. However, administrators had varying perceptions of how meta-majors were implemented. The range of administrators' responses was likely a result of ambiguous policy statutes, which is consistent with the findings of previous research (Berman 1978).

Many colleges had already implemented programs, courses, and other services to assist their developmental students; and, although we phrased the survey questions as, "Since implementing the institutional plan..." we cannot definitively guarantee that administrators' responses only included new changes to their advising processes. Therefore, we cannot quantitatively determine which outcomes were directly related to the legislation. Nevertheless, this survey was the first exploration of advising practices following the initial implementation of SB 1720, a unique context of DE enrollment choice and varied course options. We discuss our main findings below within the context of previous, relevant literature.

Institutions relied on multiple advising tools and techniques to assist the advising process, particularly when standardized placement test scores for incoming students were not available. Colleges have proven extremely innovative in their advising practices and the tools and methods they have employed. Like other states (Bracco et al. 2015), the FCS institutions were using multiple measures to assess students' likelihood of success, despite a lack of specificity in the legislation to do so.

Colleges reported varying levels of effectiveness of academic advising tools, particularly for the use of technology in advising. Across our sample there was a moderately high level of agreement that advising was effective, particularly in relation to students' exemption status and DE options. This is somewhat concerning, however, given that gateway pass rates for students enrolled have decreased since the implementation of SB 1720 (Hu et al. 2016). Administrators reported differing levels of agreement with the effectiveness of technology-based advising tools, such as an early warning system. Implementing technology, particularly a system that 
facilitates communication between and among instructors, advisors, and students, may be especially helpful for colleges with large advising caseloads. However, since few institutions reported that technology has been effective, perhaps different program platforms or professional development for advisors or instructors may be needed. If administrators do not perceive technological assistance with the advising process to be effective, institutions could consider integrating advisors into classrooms so that they can have advisors visit students during class meetings, as has been done in a community college in California (Dadgar et al. 2014).

Colleges struggled to offer adequate advising services to their students. It remains concerning that, despite SB 1720 requiring advising for all incoming students, many institutions did not mandate advising or provide advisors ample time to meet with students, a problem noted in other research (Karp and Stacey 2013). Although all institutions in the sample indicated that advising was available to all students, one administrator perceived it as not well advertised to them. This could be a function of limited staff or other resources, as many administrators indicated they had an insufficient number of advisors. With appropriate funding, institutions could consider "hiring, promoting, and developing employees who can implement the vision" of academic advising within the new DE context (Kotter 1995, p. 61). Further investigation should examine whether these institutions have substituted the functions of traditional advising with group advising (Robbins 2013) or other student support programs. Advising may be particularly helpful in this era of increased student choice, given Bahr's (2008) claims that advising is beneficial for students' success, especially those with higher academic needs.

New student orientations remained optional or needed improvement at some colleges. Indeed, three administrators reported that they did not require their students to attend a new student orientation. Further, few institutions offered separate orientations based on students' exempt status. These institutions are missing out on valuable opportunities to reach a wide range of students (Varney 2007) and target communication (Varney 2012) to maximize students' understanding of course enrollment options. However, according to Dadgar and colleagues (2014), mandatory orientations specifically for community colleges are becoming a more widespread practice, as "orientation is becoming increasingly mandatory" in these institutions (p.45).

Meta-majors have not been fully implemented into colleges' advising processes. Particularly concerning is that few administrators believed that students understood their meta-major options. This finding is critical given previous evidence that entering students may not be equipped with enough information to select a meta-major without assistance (Collins 2013), yet clearly mapped degree programs have helped support student success (Jenkins and Cho 2013). It is possible that with the advising and instructional changes required by the legislation, fully integrating meta-majors was simply a larger task than the colleges could tackle. This finding may not be unexpected, however; Kotter (1995) noted that "In reality, even successful change efforts are messy and full of surprises" (p. 67). Follow-up with administrators would be informative to understand whether and how meta-majors have become more integrated after the initial implementation period, particularly since they are now required by the legislation.

\section{Conclusion}

In this study we examined FCS administrators' perceptions of advising in the wake of SB 1270, which redesigned DE placement policies, instruction, and advising. Our 
results indicated that colleges are using a variety of tools and techniques to assist their students, but some practices are more beneficial than others. Further, additional advising resources, particularly time and personnel, appeared to be needed by most institutions. Whereas new student orientations and meta-majors did not appear integrated in many colleges, it is important that colleges fully establish these practices in order to familiarize students with their college and major pathways.

The future steps in assessing the impact of SB 1720 include continuing to survey college administrators in order to further understand their implementation of the legislation and how they have augmented advising to best suit students' needs following additional semesters of implementation. Indeed, our plans are to determine which new advising practices have been institutionalized or augmented (Kotter 1995). Despite the ability to gather information about initial implementation and advising practices following the passage of this bill, it remains to be seen how institutions' advising directly affects student outcomes, such as pass rates in DE courses, progress through gateway courses, retention from first to second semester, and reenrollment in the following fall quarter. We will continue to assess the effect of SB 1720 and address these issues with additional data sources in attempts to understand the full ramifications of a legislation that augmented DE practices for thousands of students across the State of Florida.

Acknowledgements The research reported here was supported by the Institute of Education Sciences, U.S. Department of Education, through Grant R305A160166 to Florida State University and in part by a grant from the Bill \& Melinda Gates Foundation. The opinions expressed are those of the authors and do not represent views of the Institute or the U.S. Department of Education, or the Gates Foundation.

Open Access This article is distributed under the terms of the Creative Commons Attribution 4.0 International License (http://creativecommons.org/licenses/by/4.0/), which permits unrestricted use, distribution, and reproduction in any medium, provided you give appropriate credit to the original author(s) and the source, provide a link to the Creative Commons license, and indicate if changes were made.

\section{References}

Allen, J. M., Smith, C. L., \& Muehleck, J. K. (2013). What kinds of advising are important to community college pre-and posttransfer students? Community College Review, 41, 330-345.

Backhus, D. (1989). Centralized intrusive advising and undergraduate retention. NACADA Journal, 9(1), 39-45.

Bahr, P. R. (2008). Cooling out in the community college: What is the effect of academic advising on students' chances of success? Research in Higher Education, 49, 704-732.

Bailey, T., Jeong, D. W., \& Cho, S. W. (2010). Referral, enrollment, and completion in DE sequences in community colleges. Economics of Education Review, 29, 255-270.

Berman, P. (1978). The study of macro and micro implementation of social policy. Public Policy, 26, 157-184.

Boatman, A. (2012). Evaluating institutional efforts to streamline postsecondary remediation: The causal effects of the Tennessee developmental course redesign initiative on early student academic success. Retrieved from National Center for Postsecondary Research website: http://www.postsecondaryresearch. org/i/a/document/22651_BoatmanTNFINAL.pdf

Boatman, A., \& Long, B. T. (2010). Does remediation work for all students? How the effects of postsecondary remedial and developmental courses vary by level of academic preparation. Retrieved from National Center for Postsecondary Research website: http://www.postsecondaryresearch.org/i/a/document/14155_ ABoatman_BLong_Final_9-21-10.pdf

Bracco, K. R., Austin, K., Bugler, D., \& Finkelstein, N. (2015). Reforming developmental education to better support students' postsecondary success in the common core era. San Francisco, CA: WestEd.

Brodkin, E. Z. (2008). Accountability in street-level organizations. International Journal of Public Administration, 31, 317-336. 
Calcagno, J. C., \& Long, B. T. (2008). The impact of postsecondary remediation using a regression discontinuity approach: Addressing endogenous sorting and noncompliance (No. w14194). Retrieved from National Bureau of Economic Research website: http://www.nber.org/papers/w14194

Center for College Readiness (2000). Academic advising in Texas public institutions of higher education: A summary of findings from five years of research. Houston, TX: Author.

Collins, M. L. (2013). Discussion of the joint statement of core principles for transforming remedial education. Journal of College Reading and Learning, 44, 84-94.

Dadgar, M., Nodine, T., Bracco, K. R., \& Venezia, A. (2014). Strategies for integrating student supports and academics. New Directions for Community Colleges, 2014(167), 41-51.

Dahlstrom, E., de Boor, T., Grunwald, P., \& Vockley, M. (2011). The ECAR national study of undergraduate students and information technology, 2011. Boulder, CO: EDUCAUSE.

Duffy, M. (2015). Development and implementation of multiple measure placement across states and systems: Phase 1 and Phase 2 Report Summary. Retrieved from Research for Action website: https://www. researchforaction.org/publications/development-and-implementation-of-multiple-measures-for-collegeplacement-across-states-and-systems-phase-1-and-phase-2-report-summary/

Feghali, T., Zbib, I., \& Hallal, S. (2011). A web-based decision support tool for academic advising. Educational Technology \& Society, 14(1), 82-94.

Higbee, J. L., Arendale, D. R., \& Lundell, D. B. (2005). Using theory and research to improve access and retention in DE. New Directions for Community Colleges, 2005(129), 5-15.

Honig, M. I. (Ed.). (2006). New directions in educational policy implementation. Albany, NY: State University of New York. Hu, S., Tandberg, D. A., Park, T., Nix, A., Collins, R., \& Hankerson, D. (2014). Florida developmental education reform: What do the Florida College System institutions plan to do? Tallahassee, FL: Center for Postsecondary Success.

Hu, S., Bertrand Jones, T., Brower, R., Park, T., Tandberg, D., Nix, A., Rahming, S., \& Martindale, S. (2015). Learning from the ground up: Developmental education reform at Florida college system institutions. Tallahassee, FL: Center for Postsecondary Success.

Hu, S., Park, T., Woods, C. S., Richard, K., Tandberg, D., \& Bertrand Jones, T. (2016). Probability of success: Evaluation of Florida's developmental education redesign based on cohorts of first-time-in-college students from 2009-10 to 2014-15. Tallahassee, FL: Center for Postsecondary Success.

Irlbeck, E., Adams, S., Akers, C., Burris, S., \& Jones, S. (2014). First generation college students: Motivations and support systems. Journal of Agricultural Education, 55, 154-166.

Jenkins, D., \& Cho, S. W. (2013). Get with the program... finish it: Building guided pathways to accelerate student completion. New Directions for Community Colleges, 2013(164), 27-35.

Kalamkarian, H. S., \& Karp, M. M. (2015). Student attitudes toward technology-mediated advising systems. Retrieved from Community College Research Center website: http://ccrc.tc.columbia.edu/media/k2 /attachments/student-attitudes-toward-technology-mediated-advising-systems.pdf

Karp, M. J. M., \& Stacey, G. W. (2013). Designing a system for strategic advising. Retrieved from Community College Research Center website: http://academiccommons.columbia.edu/catalog/ac:170514

Kezar, A. (2014). Higher education change and social networks: A review of research. The Journal of Higher Education, 85, 91-125.

Kirk-Kuwaye, M., \& Nishida, D. (2001). Effect of low and high advisor involvement on the academic performance of probation students. NACADA Journal, 21(1/2), 40-45.

Kot, F. C. (2014). The impact of centralized advising on first-year academic performance and second-year enrollment behavior. Research in Higher Education, 55, 527-563.

Kotter, J. P. (1995). Leading change: Why transformation efforts fail. Harvard Business Review, 73, 59-67.

Krumm, A. E., Waddington, R. J., Teasley, S. D., \& Lonn, S. (2014). A learning management system-based early warning system for academic advising in undergraduate engineering. In J. A. Larusson \& B. White (Eds.), Learning analytics (pp. 103-119). New York, NY: Springer.

Long Beach College Promise (2013). 5-Year Progress Report (2008-2013): A breakthrough in student achievement. Long Beach, CA: Author. Retrieved from http://www.longbeachcollegepromise.org/wpcontent/uploads/2013/03/LBCP-5-Year-ProgressReport.pdf

Matland, R. (1995). Synthesizing the implementation literature: The ambiguity-conflict model of policy implementation. Journal of Public Administration Research and Theory, 5, 145-174.

McLaughlin, M. W. (1987). Learning from experience: Lessons from policy implementation. Educational Evaluation and Policy Analysis, 9, 171-178.

McLaughlin, M. W. (2006). Implementation research in education: Lessons learned, lingering questions and new opportunities. In M. I. Honig (Ed.), New directions in education policy implementation (pp. 209-228). Albany, NY: State University of New York Press.

Melguizo, T., Hagedorn, L. S., \& Cypers, S. (2008). Remedial/DE and the cost of community college transfer: A Los Angeles County sample. The Review of Higher Education, 31, 401-431. 
Ngo, F., \& Kwon, W. W. (2015). Using multiple measures to make math placement decisions: Implications for access and success in community colleges. Research in Higher Education, 56, 442-470.

Park, T. J., Tandberg, D. A., Hu, S., \& Hankerson, D. (2016). One policy, disparate reactions: Institutional responses in Florida's developmental education reform. Community College Journal of Research and Practice, 40, 824-837.

Percival, G. (2004). The influence of local contextual characteristics on the implementation of a statewide voter initiative: The case of California's Substance Abuse and Crime Prevention Act (Proposition 36). The Policy Studies Journal, 32, 589-610.

Perin, D. (2006). Can community colleges protect both access and standards? The problem of remediation. Teachers College Record, 108, 339-373.

Person, A., Rosenbaum, J., \& Deil-Amen, R. (2006). Student planning and information problems in different college structures. Teachers College Record, 108(3), 374-396.

Pretlow, J., III, \& Wathington, H. D. (2012). Cost of developmental education: An update of Breneman and Harlow. Journal of Developmental Education, 36(2), 3-44.

Robbins, R. (2013). 2011 national survey of academic advising. (Monograph No. 25). Manhattan, KS: National Academic Advising Association. Retrieved from the NACADA Clearinghouse of Academic Advising Resources website: http://www.nacada.ksu.edu/tabid/3318/articleType/ArticleView/articleId/94/article.aspx

Safran, S., \& Visher, M. G. (2010). Case studies of three community colleges: The policy and practice of assessing and placing students in DE courses. New York, NY: National Center for Postsecondary Research. Senate Bill § 1720 (F. L. 2013).

Scott-Clayton, J., \& Rodriguez, O. (2012). Development, discouragement, or diversion? New evidence on the effects of college remediation. Education Finance and Policy, 10, 4-45.

Scott-Clayton, J., Crosta, P., \& Belfield, C. (2014). Improving the targeting of treatment: Evidence from college remediation. Educational Evaluation and Policy Analysis, 36, 371-393.

Spillane, J. P., Reiser, B. J., \& Gomez, L. M. (2006). Policy implementation and cognition. In M. I. Honig (Ed.), New directions in educational policy implementation (pp. 47-64). Albany, NY: State University of New York Press.

Swecker, H. K., Fifolt, M., \& Searby, L. (2013). Academic advising and first-generation college students: A quantitative study on student retention. NACADA Journal, 33(1), 46-53.

Van Meter, D. S., \& Van Horn, C. E. (1975). The policy implementation process: A conceptual framework. Administration and Society, 6, 445-488.

Varney, J. (2007). Intrusive advising. Academic Advising Today, 30(3), 11-13.

Varney, J. (2012). Proactive (intrusive) advising! Academic Advising Today, 35(3), 1-3.

Young-Jones, A. D., Burt, T. D., Dixon, S., \& Hawthorne, M. J. (2013). Academic advising: does it really impact student success? Quality Assurance in Education, 21, 7-19. 